\title{
Daya Antibakteri Ekstrak Daun Seledri (Apium graveolens L.) terhadap Porphyromonas gingivalis
}

(Antibacterial Activity of Celery Leaves (Apium graveolens L.) against Porphyromonas gingivalis)

Anisa Luthfiyani' ${ }^{1}$, Peni Pujiastuti² ${ }^{2}$ Melok Aris W'

1 Fakultas Kedokteran Gigi Universitas Jember

2 Bagian Periodonsia, Fakultas Kedokteran Gigi Universitas Jember

\begin{abstract}
Abstrak
Latar belakang: daun seledri mengandung zat antibakteri yang bisa dimanfaatkan sebagai obat. Kandungan tersebut diantaranya flavonoid, saponin dan tanin. Tujuan: penelitian ini bertujuan untuk mengetahui daya antibakteri daun seledri (Apium graveolens L.) terhadap pertumbuhan Porphyromonas gingivalis (P. gingivalis). Metode: daun seledri diekstrak dengan metode maserasi dengan pelarut etanol $96 \%$. Metode uji antibakteri terhadap $P$. gingivalis menggunakan metode sumuran pada media BHI-A. Konsentrasi ekstrak daun seledri yang digunakan pada penelitian ini yaitu 6,25\%, 12.5\%, 25\%, 50\% dan 100\%. Hasil penelitian: menunjukkan ekstrak daun seledri (Apium graveolens L.) tidak memiliki kemampuan menghambat pertumbuhan Porphyromonas gingivalis. Kesimpulan: daun seledri tidak memiliki daya antibakteri terhadap Porphyromonas gingivalis pada konsentrasi $6,25 \%, 12.5 \%, 25 \%, 50 \%$ dan $100 \%$.
\end{abstract}

Kata kunci : Antibakteri, Daun seledri, Porphyromonas gingivalis

\section{Abstract}

Background: celery leaves contain antibacterial substances that can be used as medicine. These contents include flavonoids, saponins and tannins. Purpose: the aim of this study was to determine the antibacterial effect of celery leaves (Apium graveolens L.) on the growth of Porphyromonas gingivalis (P. gingivalis). Methods: celery leaves were extracted by maceration method with $96 \%$ ethanol. The antibacterial test method against $P$. gingivalis using the well diffusion method on BHI-A media. The concentrations of celery leaf extract used in this study were $6.25 \%, 12.5 \%$, 25\%, 50\% and $100 \%$. Result: The results showed that celery leaves extract (Apium graveolens L.) didn't have the ability to inhibit the growth of Porphyromonas gingivalis. Conclusion: celery leaves didn't have antibacterial effect against Porphyromonas gingivalis in 6,25\%, $12.5 \%, 25 \%, 50 \%$ and $100 \%$ concentrations.

Keywords : Antibacterial, Celery leaves, Porphyromonas gingivalis

Korespondensi (correspondence) : Anisa Luthfiyani, Peni Pujiastuti, Melok Aris W, Fakultas Kedokteran Gigi Universitas Jember Jalan Kalimantan 37, Jember 68121. Email: anisah.Iuthfiyani@gmail.com

Penyakit periodontal adalah suatu keradangan kronis pada jaringan penyangga gigi (periodontium).' Penyakit ini memiliki prevalensi cukup tinggi di Indonesia dimana penyakit periodontal pada semua kelompok umur di Indonesia adalah sebesar 96,58\% berdasarkan riset kesehatan dasar tahun 2013.2 Menurut sumber data dari Kementrian Kesehatan Republik Indonesia, kelainan periodontal menduduki peringkat ke 8 dari 10 penyakit utama di rumah sakit.' Penyakit periodontal juga tidak bisa dianggap remeh karena apabila dibiarkan semakin parah akan merusak struktur tulang dan menyebabkan saku periodontal semakin dalam yang kemudian akan menjadi tempat bagi berbagai jenis bakteri. Bakteri kemudian bisa masuk ke sistem peredaran darah dan menyebar ke bagian lain dari tubuh. ${ }^{3}$

Penyakit periodontal dapat disebabkan oleh suatu bakteri plak yang menyerang jaringan penyangga gigi meliputi gingiva, ligamen periodontal, sementum dan tulang alveolar. Penyakit periodontal dibagi menjadi 2 yaitu penyakit gingiva dan penyakit periodontal.' Bakteri plak penyebab penyakit periodontal salah satunya adalah Porphyromonas gingivalis (P. gingivalis). Bakteri ini sangat berpengaruh dalam inisiasi dan keparahan penyakit periodontal. ${ }^{4} P$. gingivalis dapat menyebabkan perubahan patologik pada jaringan periodontal dengan pengaktifan respons imun dan inflamatori inang, dan secara langsung mempengaruhi sel-sel periodonsium. $P$. gingivalis juga diketahui dapat memproduksi berbagai faktor virulensi patogenik, seperti lipopolisakarida dan hidrogen sulfida, yang dapat menginduksi inang untuk melepaskan Interleukin- 1 dan TNFa. ${ }^{5}$

P. gingivalis dapat menempel pada gigi dalam bentuk plak. Mekanisme terjadinya plak diawali dari terbentuknya pelikel pada pemukaan gigi yang berwarna transparan, kemudian bakteri akan menempel dan berproliferasi sehingga warna akan berubah menjadi kekuningan. Pelikel terdiri atas glikoprotein yang diendapkan oleh saliva yang terbentuk segera setelah penyikatan gigi. Perkembangbiakan bakteri membuat lapisan plak bertambah tebal karena adanya hasil metabolisme dan adhesi dari bakteri-bakteri pada permukaan luar plak P.gingivalis akan melekat pada bakteri yang sudah melekat ke pelikel, interaksi ini disebut dengan proses koagregasi. 6.7

Upaya yang dapat dilakukan untuk mengurangi terbentuknya plak adalah dengan melakukan kontrol plak. Kontrol plak dapat dilakukan secara mekanik dan kimiawi. Kontrol plak secara mekanik adalah dengan cara menyikat gigi. Kontrol plak secara kimiawi adalah dengan cara berkumur dengan cairan anti bakteri atau obat kumur. ${ }^{8}$ 
Obat kumur yang sering dipakai karena efektivitasnya terhadap periodontal patogen salah satunya adalah chlorhexidine. Chlorhexidine dipercaya sebagai obat kumur yang mampu mengurangi pembentukan plak, menghambat pertumbuhan plak dan mencegah terjadinya penyakit periodontal. Hal ini dikarenakan sifat dari chlorhexidine sendiri, yaitu bakterisid dan bakteriostatik terhadap berbagai macam bakteri.? Penggunaan chlorhexidine dalam jangka waktu lebih dari 2 minggu ternyata memiliki efek samping di antaranya menyebabkan rasa terbakar pada mukosa mulut, mengganggu indera perasa, erosi mukosa mulut, dan kekeringan pada rongga mulut. 10 Untuk itu diperlukan alternatif bahan lain sebagai pengganti obat kumur chlorhexidine, salah satunya yaitu penggunaan obat kumur herbal dari bahan daun seledri.

Seledri (Apium graveolens L.) oleh masyarakat Indonesia lebih dikenal sebagai sayuran. Akan tetapi ternyata seledri bisa bermanfaat untuk menurunkan kolesterol, sebagai antibakteri, antioksidan dan antiinflamasi. Kandungan dalam seledri yang bisa bermanfaat sebagai antibakteri diantaranya yaitu flavonoid, saponin dan tannin. ${ }^{11,12}$

Flavonoid merupakan kelompok senyawa fenol yang mempunyai kecenderungan untuk mengikat protein.13 Flavonoid mempunyai kemampuan untuk membentuk senyawa kompleks dengan protein melalui ikatan hidrogen sehingga struktur protein pada bakteri terganggu, dan protein tidak dapat berfungsi lagi sehingga terjadi kerusakan/denaturasi protein dan asam nukleat. Denaturasi tersebut menyebabkan koagulasi protein serta mengganggu metabolisme bakteri dan fungsi fisiologis bakteri.14 Mekanisme kerja saponin sebagai antibakteri termasuk dalam kelompok antibakteri yang mengganggu permeabilitas membran sel bakteri.13 Senyawa ini dapat berdifusi melalui membran luar dan dinding sel yang rentan, lalu mengikat membran sitoplasma dan mengganggu dan mengurangi kestabilan. Hal ini menyebabkan sitoplasma bocor keluar dari dalam sel yang kemudian mengakibatkan kematian sel. ${ }^{15}$ Mekanisme kerja tanin sebagai antibakteri berhubungan dengan target penyerangan tanin terhadap kerusakan polipeptida yang terdapat pada dinding sel bakteri sehingga mengganggu sintesa peptidoglikan yang menjadikan pembentukan dinding sel tidak sempurna. ${ }^{16}$

Penelitian sebelumnya dilakukan Majidah (2014) bertujuan untuk mengetahui daya antibakteri daun seledri terhadap $S$. mutans. Daun seledri diekstraksi menggunakan etanol $96 \%$ dengan metode ekstraksi maserasi menunjukkan hasil bahwa daun seledri dengan konsentrasi $12,5 \%, 25 \%, 50 \%, 100 \%$ mempunyai daya antibakteri terhadap $S$. Mutans.

\section{METODE PENELITIAN}

Jenis penelitian ini adalah eksperimental. laboratoris dengan rancangan penelitian posttest only control group design. Penelitian dilaksanakan di Laboraturium Mikrobiologi Fakultas Kedokteran Gigi Universitas Jember, Laboraturium Bioscience Fakultas Kedokteran Gigi Universitas Jember, Laboratorium Tanaman Politeknik Negeri Jember pada bulan September 2018-Januari 2019. Jumlah sampel pada penelitian ini adalah 4 buah untuk setiap kelompok perlakuan yang telah memenuhi hasil perhitungan jumlah sampel minimal menurut Federer. Kriteria daun seledri yang digunakan untuk penelitian ini adalah daun seledri lokal yang baru dipetik dari desa Biting Kecamatan Arjasa Jember. Daun yang utuh atau tidak cacat dan masih segar berwarna hijau dengan panjang 2-7,5 cm dan lebar 2-5 $\mathrm{cm}$.

Cara pembuatan ekstrak daun seledri dengan cara daun seledri dideterminasi, dipisahkan dari batang dan dipilih yang sesuai dengan kriteria. Daun seledri kemudian dicuci dan ditiriskan untuk menghilangkan sisa air. Pengeringan daun seledri dengan cara dipanaskan dalam oven suhu $40^{\circ} \mathrm{C}$ selama 3 hari 11 jam sampai kadar air yang ada dalam daun seledri habis dan kering. Daun seledri yang sudah kering dihaluskan dengan menggunakan blender dan diayak sehingga didapatkan bentukan serbuk atau bubuk halus. Ekstraksi dengan metode maserasi yaitu dicampur dengan etanol $96 \%$ dengan perbandingan $1 / 10 \mathrm{~b} / \mathrm{v}$. Kemudian didiamkan selama 24 jam dalam wadah tertutup dengan 6 jam pertama sesekali diaduk. Setelah 24 jam hasil rendaman selanjutnya disaring dengan corong yang telah dilapisi kertas saring. Langkah yang terakhir adalah melakukan penguapan dengan rotary evaporator pada hasil filtrat selama 11 jam hingga didapatkan ekstrak buah kersen yang kental. Rendemen yang dihasilkan untuk ekstrak buah kersen konsentrasi $100 \%$ adalah $37,12 \% .{ }^{12}$

Pengenceran dilakukan dengan aquades steril untuk mendapat serial dilution konsentrasi $6,25 \%, 12,5 \%, 25 \%$ dan $50 \%$, setalah itu dilakukan pemberian label pada 4 petridish masing-masing pada bagian bawahnya dibagi menjadi 7 daerah sama besar menggunakan spidol dan diberi label bertuliskan : E100, E50, E25, E12,5, E6,25, K+ dan K-. Untuk membedakan ke 4 petridish tersebut maka diberi label nomer 1 sampai 4.

Penelitian ini menggunakan metode difusi sumuran. Pada lubang sumuran daerah E100 dimasukkan ekstrak daun seledri 100\%, di daerah E50 dimasukkan ekstrak daun seledri $50 \%$, di daerah E25 dimasukkan ekstrak daun seledri $25 \%$, di daerah E12,5 dimasukkan 
ekstrak daun seledri $12,5 \%$, di daerah $\mathrm{E} 6,25$ dimasukkan ekstrak daun seledri 6,25\% masing - masing sebanyak $20 \mu \mathrm{l}$ menggunakan mikropipet; didaerah K- dibuat satu lubang sumuran yang diisi aquadest steril sebanyak 20 $\mu l$ dengan mikropipet dan $\mathrm{K}+$ juga dibuat satu lubang sumuran yang diisi chlorhexidine gluconate $0,2 \%$ sebanyak $20 \mu \mathrm{l}$ dengan mikropipet. Seluruh petridish dimasukkan ke dalam desicator untuk mendapat suasana anaerob dan diinkubasi dalam diinkubator dengan suhu $37^{\circ} \mathrm{C}$ selama 24 jam. Setelah 24 jam, dilakukan pengamatan dan pengukuran besarnya zona hambat terhadap pertumbuhan $P$. gingivalis.

Besarnya hambatan pertumbuhan $P$. gingivalis dengan metode difusi sumuran diketahui dengan mengukur diameter zona bening disekitar lubang sumuran menggunakan jangka sorong digital. Zona bening menunjukkan kepekaan bakteri terhadap bahan antibakteri yang digunakan sebagai bahan uji dan dinyatakan dengan diameter zona hambat. Pengukuran diameter zona hambat yaitu dengan membalikkan petridish sehingga terlihat daerah bening di sekitar lubang sumuran, kemudian dengan menggunakan jangka sorong digital zona hambat diukur diameternya dan dicatat. Jika zona hambat berbentuk lonjong, maka pengukuran dilakukan pada diameter yang panjang dikurangi diameter lubang sumuran dan diameter yang pendek dikurangi diameter lubang sumuran kemudian keduanya dijumlah dan dibagi.

Data yang diperoleh kemudian dilakukan uji normalitas menggunakan uji Saphiro-Wilk dan uji homogenitas menggunakan Lavene Test. Apabila kedua uji menunjukkan data normal dan homogen maka dilakukan uji parametrik dengan Anova Satu Arah kemudian apabila terdapat perbedaan dilanjutkan dengan uji LSD untuk mengetahui perbedaan antar kelompok. Tetapi jika data yang diperoleh tidak berdistribusi normal atau variasi data yang diperoleh tidak homogen, maka dilakukan analisis menggunakan uji statistik nonparametrik Kruskal Wallis yang bertujuan untuk membandingkan lebih dari dua kelompok sampel bebas. Apabila data menunjukkan ada beda, maka dilanjutkan uji perbedaan antar kelompok menggunakan uji statistik nonparametrik Mann-Whitney. Akan tetapi pada penelitian ini tidak dilakukan analisa data dikarenakan hasil pengamatan menunjukkan tidak terbentuk zona bening disekitar sumuran.

\section{HASIL PENELITIAN}

Penelitian ini merupakan penelitian eksperimental laboratoris dengan tujuan untuk mengetahui efek antibakteri ekstrak daun seledri (Apium graveolens L.) terhadap $P$. gingivalis. Hasil pengamatan zona bening dapat dilihat pada tabel 1 dan gambar 1 . Berdasarkan hasil penelitian yang telah dilakukan didapatkan hasil bahwa ekstrak daun seledri (Apium graveolens L.) konsentrasi $100 \%, 50 \%, 25 \%, 12,5 \%$ dan $6,25 \%$ tidak memiliki zona hambat terhadap P. gingivalis (Gambar 1). Berdasarkan tabel 1 menunjukkan bahwa ekstrak daun seledri (Apium graveolens L.) konsentrasi $100 \%, 50 \%, 25 \%, 12,5 \%$ dan $6,25 \%$ tidak memiliki daya hambat terhadap $P$. gingivalis. Hal ini terlihat dari hasil pengamatan yaitu tidak terdapat daerah bening disekitar sumuran pada ekstrak daun seledri konsentrasi $100 \%, 50 \%, 25 \%, 12,5 \%$ dan $6,25 \%$. Sedangkan pada kontrol positif yaitu clorhexidine terdapat daerah bening disekitar sumuran yang setelah diukur menggunakan jangka sorong digital hasilnya rata-rata sebesar $9,40 \mathrm{~mm}$. Ekstrak daun seledri (Apium graveolens L.) tidak memiliki daya hambat terhadap $P$. gingivalis. Sehingga dapat disimpulkan bahwa ekstrak daun seledri (Apium graveolens L.) tidak memiliki daya antibakteri terhadap $P$. gingivalis. pertumbuhan $P$. gingivalis $(n=4$

\begin{tabular}{cc}
\multicolumn{2}{c}{ pertumbuhan $P$. gingivalis $(\mathrm{n}=4)$} \\
\hline Groups & Zona hambat \\
\hline E $6,25(6,25 \%)$ & $0,00 \pm 0,00$ \\
E $12,5(12,5 \%)$ & $0,00 \pm 0,00$ \\
E $25(25 \%)$ & $0,00 \pm 0,00$ \\
E $50(50 \%)$ & $0,00 \pm 0,00$ \\
E $100(100 \%)$ & $0,00 \pm 0,00$ \\
K(+) (Chlorhexidine) & $9,40 \pm 0,47$ \\
K(-) (Aquades) & $0,00 \pm 0,00$ \\
\hline
\end{tabular}

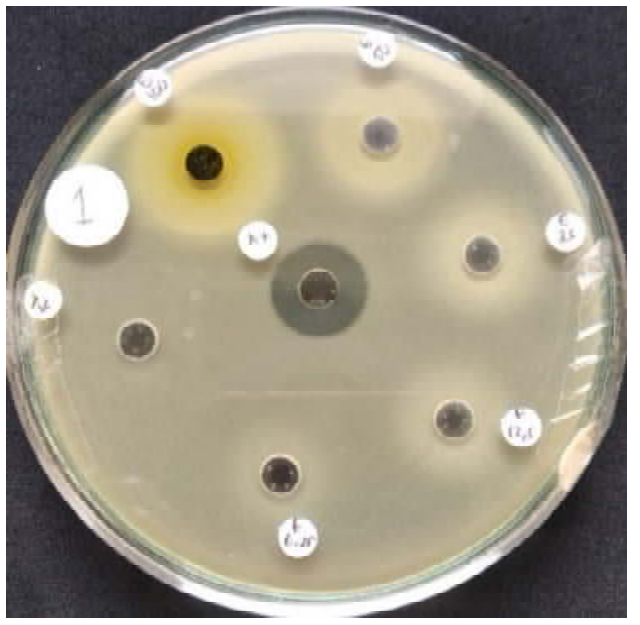

Gambar 1. Zona hambat yang terbentuk di sekitar lubang sumuran

\section{PEMBAHASAN}

Berdasarkan hasil penelitian ekstrak daun seledri (Apium graveolens L.) tidak memiliki daya hambat terhadap $P$. gingivalis pada seluruh konsentrasi ekstrak sehingga tidak dilanjutkan untuk pencarian konsentrasi minimal dalam menghambat $P$. gingivalis. Beberapa hal yang mungkin menjadi penyebab tidak terbentuknya zona bening disekitar sumuran yaitu yang pertama 
kemungkinan disebabkan karena kandungan zat antibakteri yang terdapat dalam daun seledri yang terlampau sedikit. Kandungan dalam daun seledri yang bisa bermanfaat sebagai antibakteri diantaranya yaitu flavonoid $1,7 \%$, saponin $0,36 \%$ dan tanin $1 \% .12$ Kandungan dalam daun seledri yang sedikit kemungkinan tidak bisa menembus dinding sel $P$. gingivalis. Struktur dinding sel bakteri gram negatif mengandung 3 polimer senyawa mukokompleks yang terletak di luar lapisan peptidoglikan (murein). Ketiga polimer ini terdiri dari lipoprotein yaitu senyawa protein yang mempunyai fungsi menghubungkan antara selaput luar dengan lapisan peptidoglikan (murein). Selaput luar yang merupakan selaput ganda yang mengandung senyawa fosfolipid dan sebagian besar dari senyawa fosfolipid ini terikat oleh molekul-molekul lipopolisakarida pada lapisan atasnya. Selain itu juga terdapat lapisan lipopolisakarida yaitu senyawa yang mengandung lipid yang kompleks. Molekulmolekul lipopolisakarida ini berfungsi sebagai penyusun dinding sel bakteri gram negatif yang dapat mengeluarkan sejenis racun (toksin) yang disebut endotoksin. ${ }^{17}$

Pada lapisan terluar dinding sel $P$. gingivalis yaitu lipoprotein terdapat molekul protein yang disebut porin yang bersifat hidrofilik. Porin yang terkandung pada membran terluar tersebut menyebabkan molekul-molekul protein yang disebut porin yang bersifat hidrofilik. Porin yang terkandung pada membran terluar tersebut menyebabkan molekul-molekul komponen ekstrak lebih sukar masuk ke dalam sel bakteri. Porin menyebabkan difusi pasif senyawa hidrofilik dengan berat molekul rendah seperti glukosa dan asam amino. Sedangkan molekul dengan berat molekul besar seperti molekul antibakteri termasuk molekul aktif ekstrak etanol daun seledri akan mengalami kesulitan menembus selaput ini. ${ }^{18}$ Kandungan zat antibakteri dalam daun seledri yang terlampau sedikit ditambah dengan struktur dinding sel bakteri gram negatif yang kompleks dan sulit ditembus oleh molekul antibakteri dalam daun seledri yang kemungkinan menjadi penyebab tidak terbentuknya zona bening disekitar sumuran.

Kemungkinan kedua yang mungkin berpengaruh terhadap hasil penelitian yang menunjukkan tidak terdapat daya hambat yaitu dari faktor pengeringan simplisia daun seledri yang terlalu lama. Pengeringan merupakan usaha untuk menurunkan kadar air bahan sampai ke tingkat yang diinginkan. Beberapa faktor yang mempengaruhi proses pengeringan, antara lain waktu pengeringan, suhu pengeringan, kelembapan udara di sekitarnya, kelembapan bahan atau kandungan air dari bahan, ketebalan bahan yang dikeringkan, sirkulasi udara dan luas permukaan bahan. Pengeringan harus disesuaikan dengan bahan tanaman yang akan dikeringkan. Jika bahan berasal dari akar, daun, bunga dan buah maka suhu dan metode pengeringan perlu diperhatikan.
Apabila tidak ditangani secara benar akan mengakibatkan berkurangnya kandungan zat aktif. Bahan yang berasal dari bunga dan daun harus tidak mengubah warna dan aroma aslinya, karena daun dan bunga mudah mengalami kerusakan selama pengeringan. Daun, herba dan bunga dapat dikeringkan dengan kisaran suhu $20-40^{\circ} \mathrm{C}$ sedangkan kulit batang dan akar masingmasing pada suhu $30^{\circ} \mathrm{C}$ dan $65^{\circ} \mathrm{C} .19$

Pada penelitian ini pengeringan dilakukan didalam oven pada suhu $40^{\circ} \mathrm{C}$ selama 3 hari 11 jam. Suhu yang digunakan yaitu $40^{\circ} \mathrm{C}$ telah sesuai dengan literatur yang ada, akan tetapi untuk waktu pengeringan yaitu 3 hari 11 jam kemungkinan menjadi faktor yang dapat mempengaruhi berkurangnya kandungan zat aktif yang terdapat di dalam daun seledri. Penelitian sebelumnya tentang daya hambat ekstrak etanol daun seledri yang dilakukan oleh Majidah (2014) proses pengeringan daun seledri dilakukan selama 20 jam dan dihasilkan ekstrak etanol daun seledri yang dapat menghambat pertumbuhan bakteri. Pengeringan daun seledri didalam oven yang terlalu lama yaitu selama 3 hari 11 jam kemungkinan menyebabkan berkurangnya kandungan zat aktif yang terdapat dalam daun seledri sehingga menjadi faktor penyebab tidak terbentuknya daya hambat disekitar sumuran.

Faktor ketiga yang mungkin berpengaruh terhadap hasil penelitian yang menunjukkan tidak terdapat daya hambat yaitu bakteri kemungkinan mengalami resistensi karena perubahan lingkungan yang kurang menguntungkan bagi bakteri. Lingkungan yang kurang menguntungkan salah satu contohnya yaitu karena pemberian ekstrak etanol daun seledri yang mengandung beberapa macam zat antibakteri. Adanya perubahan lingkungan yang kurang menguntungkan tersebut akan akan berpengaruh terhadap bakteri yaitu bakteri bisa mati, pertumbuhannya terhambat atau bahkan mampu beradaptasi dengan lingkungan. ${ }^{20}$ Bakteri telah dirancang agar bisa beradaptasi. Struktur sel bakteri dan informasi genetik bakteri dapat berubah (sel mengalami mutasi). Beberapa perubahan dapat bersifat reversible atau irreversible dan bahkan dapat diteruskan ke generasi bakteri berikutnya. Faktor-faktor yang dapat mempengaruhi bakteri untuk beradaptasi diantaranya yaitu perubahan suhu, $\mathrm{pH}$ dan konsentrasi ion seperti natrium. Salah satu contoh adaptasi pada bakteri gram negatif adalah perubahan molekul yang disebut lipopolisakarida. Lipopolisakarida dapat berubah menjadi lebih tahan air atau bahkan kurang tahan terhadap air. Perubahan-perubahan ini dapat mempengaruhi kemampuan agen antibakteri untuk membunuh bakteri. ${ }^{21}$ Kemungkinan bakteri $P$. gingivalis pada penelitian ini pertumbuhannya tidak dapat dihambat dikarenakan $P$. gingivalis meskipun telah diberikan ekstak etanol daun seledri, bakteri masih bisa beradaptasi dengan perubahan 
lingkungan yang ada (pemberian ekstrak etanol daun seledri). Sehingga kemungkinan bakteri mengalami resistensi karena bakteri telah beradaptasi.

Terdapat penelitian sebelumnya tentang daya antibakteri ekstrak daun seledri yang diekstraksi menggunakan karbon dioksida cair. Metode ekstraksi ini digunakan untuk mengekstrak kandungan minyak atsiri yang terdapat didalam daun seledri. Salah satu komponen minyak atsiri yang terdapat dalam daun seledri adalah pthalides. Pada penelitian ini menunjukkan hasil bahwa ekstrak daun seledri yang diekstraksi menggunakan karbon dioksida cair efektif dalam menghambat pertumbuhan Bacillus cereus (bakteri gram positif), akan tetapi bersifat resisten terhadap bakteri Citrobacter freundii (gram negatif anaerob) dan Proteus vulgaris (bakteri gram negatif).22 Penelitian ini sejalan dengan penelitian daya antibakteri ekstrak daun seledri terhadap $P$. gingivalis karena pada penelitian tersebut ekstrak daun seledri yang diekstraksi dengan menggunakan karbon dioksida cair tidak dapat menghambat bakteri jenis gram negatif.

Berdasarkan hasil penelitian yang telah dilakukan dapat disimpulkan bahwa ekstrak daun seledri (Apium graveolens L.) tidak memiliki kemampuan menghambat pertumbuhan $P$. gingivalis yang kemungkinan disebabkan karena kandungan zat antibakteri dalam daun seledri yang terlalu sedikit, waktu pengeringan daun seledri pada suhu $40^{\circ} \mathrm{C}$ yang terlalu lama dan bakteri mengalami resistensi. Perlu dilakukan penelitian lebih lanjut dengan metode ekstraksi pengeringan pada suhu $40^{\circ} \mathrm{C}$ dengan waktu yang lebih tepat untuk mengetahui daya antibakteri ekstrak daun seledri (Apium graveolens L.) terhadap P. gingivalis dan daya antibakteri ekstrak daun seledri (Apium graveolens L.) terhadap mikroflora lain di rongga mulut.

\section{DAFTAR PUSTAKA}

1. Pujiastuti P. Obesitas dan Penyakit Periodontal. Jurnal Kedokteran Gigi Unej. 2012. 9(2): 82-5.

2. Tambunan EGR., Pandelaki K, dan Mintjelungan CN. Gambaran Penyakit Periodontal pada Penderita Diabetes Melitus di Rumah Sakit Umum Pusat Prof. dr. R. D Kandou Manado. Jurnal e-GiGi (eG). 2015; 3(2).

3. Larasati R. Hubungan Kebersihan Mulut dengan Penyakit Sistemik dan Usia Harapan Hidup. Jurnal Skala Husada. 2012; 9(1): 97-104.

4. Fitriyana N., Arina YMD, Harmono $H$, Susilawati IDA. Pemaparan Bakteri Porphyromonas gingivalis Mempengaruhi Produksi Superoksid Netrofil. Dentofasial. 2013; 12(3): 152-8.
5. Kusumawardani B., Pujiastuti $P$, dan Sari DS. Uji Biokimiawi Sistem API 20 A Mendeteksi Porphyromonas gingivalis Isolat Klinik dari Plak Subgingiva Pasien Periodontitis Kronis. Jurnal PDGI. 2010; 59(3): 110-4.

6. Ladytama $\operatorname{Rr}$ S., Nurhapsari A, dan Baehaqi M. Efektivitas Larutan Ekstrak Jeruk Nipis (Citrus aurantifolia) sebagai Obat Kumur terhadap Penurunan Indeks Plak pada Remaja Usia 12 - 15 tahun Studi di SMP Nurul Islami, Mijen,Semarang. Odonto Dental Journal. 2014; 1(1).

7. Vera. Perbandingan Efektifitas Metode Pengajaran Cara Menyikat Gigi Terhadap Penurunan Indeks Plak Pada Anak Usia 3-5 Tahun di Sekolah Bodhicitta Medan. Skripsi. Medan: Fakultas Kedokteran Gigi Universitas Sumatera Utara. 2010

8. Penda PAC, Kaligis SHM, Juliatri. Perbedaan Indeks Plak Sebelum dan Sesudah Pengunyahan Buah Apel. Jurnal e-GiGi (eG). 2015; 3(2).

9. Sinaredi BR., Pradopo S, dan Wibowo TB. Daya Antibakteri Obat Kumur Chlorhexidine, Povidone lodine, Fluoride Suplementasi Zinc terhadap Streptococcus mutans dan Porphyromonas gingivalis. Dent. J. (Majalah Kedokteran Gigi). 2014; 47(4): 211-4.

10. Attamimi FZ., Ruslami R, dan Maskoen AM. Uji Aktivitas Antibakteri Ekstrak Kasar Umbi Sarang Semut (Myrmecodia pendens) Dibanding dengan Klorheksidin terhadap Streptococcus sanguinis. MKB. 2017; 49(2).

11. Saputra, O., dan T. Fitria. 2016. Khasiat Daun Seledri (Apium graveolens) terhadap Tekanan Darah Tinggi pada Pasien Hiperkolestrolemia. Majority. 5(2): 120.

12. Majidah D. Daya Antibakteri Ekstrak Daun Seledri (Apium graveolens L.) terhadap Pertumbuhan Streptococcus mutans. Skripsi. Jember: Fakultas Kedokteran Gigi Universitas Jember. 2014

13. Sriyono RAN., dan Andriani I. Daya Antibakteri Ekstrak Etanol Kulit Manggis (Garcinia mangostana linn.) terhadap Bakteri Porphyromonas gingivalis. IDJ. 2013; 2(2).

14. Heni SA, dan Zaharah TA. Efektivitas Antibakteri Ekstrak Kulit Batang Belimbing Hutan (Baccaurea angulata Merr.) Terhadap Staphylococcus aureus dan Escherechia colli. JKK. 2015; 4(1): 89-90. 
15. Armedita D., Asfrizal V, dan Amir M. Aktivitas Antibakteri Ekstrak Etanol Daun, Kulit Batang, dan Getah Angsana (Pterocarpus indicus willd) Terhadap Pertumbuhan Streptococcus mutans. Odonto Dental Journal. 2018; 5(1).

16. Ngajow M., Abidjulu J, dan Kamu VS. Pengaruh Antibakteri Ekstrak Kulit Batang Matoa (Pometia pinnata) terhadap Bakteri Staphylococcus aureus secara In vitro. JURNAL MIPA UNSRAT ONLINE. 2013; 2(2): 128-132.

17. Fitriah, Mappiratu, dan Prismawiryanti. Uji Aktivitas Antibakteri Ekstrak Daun Tanaman Johar (Cassia siamea Lamk.) dari beberapa tingkat kepolaran pelarut. KOVALEN. 2017; 3(3): 242-51.

18. Poeloengan M., dan Andriani. Kandungan Senyawa Aktif dan Daya Antibakteri Daun Sambung Darah. Jurnal Veteriner. 2013; 14(2): 45-152.

19. Hernani dan Nurdjanah R. Aspek Pengeringan dalam Mempertahankan Kandungan Metabolit Sekunder pada
Tanaman Obat. Perkembangan Teknologi TRO. 2009. 21 (2): 33-9.

20. Beales, N. Adaptation of Microorganisms to Cold Temperatures, Weak Acid Preservatives, Low $\mathrm{pH}$, and Osmotic Stress: A Review. COMPREHENSIVE REVIEWS IN FOOD SCIENCE AND FOOD SAFETY. 2004. 3.

21. Groisman, E. A. Principles of Bacterial Pathogenesis. Burlington: Academic Press. 2000

22. Sipailiene A., Sarkinas A, Venskutonis R, Cypiene $V$. Composition and Antimicrobial Activity of Celery (Apium graveolens) Leaf and Root Extracts Obtained with Liquid Carbon Dioxide. 2015

https://www.researchgate.net/publicati on/267945326_Composition_and_Antimi crobial_Activity_of_Celery_Apium_grave olens_Leaf_and_Root_Extracts_Obtained _with_Liquid_Carbon_Dioxide. [Diakses pada 12 Juni 2019]. 